The Sources of Eddington's Philosophy

By Prof. Herbert Dingle. (Eighth Arthur Stanley Eddington Memorial Lecture, 2 November 1954.) Pp. vi +64. (Cambridge: At the University Press, 1954.) 3s. 6d. net.

$\mathrm{T}$ HE annual Eddington Memorial Lecture is expected to discuss some topic which would have interested Eddington. It is not necessarily expected to discuss Eddington himself, and it is conceivable that the two tasks are mutually incompatible. Nevertheless, recollecting the antithesis to Eddington which Prof. Herbert Dingle maintained in the former's life-time, it is important to-day to read the considered judgment of ten years later. 'The old instinctive antagonism is there, the empiricist's mistrust of the purely rational share in scientific reasoning, a share which undoubtedly Eddington did over-emphasize. Dingle himself is not always to be acquitted of over-emphasis; for example, on p. 31 : "I do not think that anyone but Eddington would have had the amazing combination of courage, perverted outlook and persuasive skill necessary to advance such an utterly fantastic notion".

What is novel and important in this lecture is a reclassification of some subjective and objective aspects of the internal and external worlds, which the author claims to draw from his critique of Eddington, but which, at least in shrewd and clear manner of statement, has here an originality of its own. It would be good to see in a future publication a de novo statement of Dingle's own situation concerning subjective elements in knowledge, without it being loaded by his disagreements with Eddington which tend to veil the development of genuinely original ideas.

But to read 'Dingle on Eddington' must always arouse a frustrated wish to have also an Eddington on Dingle; the great pioneer might possibly speak of his critic as in the latter's final words of this lecture: "He did not know what he was doing, but I believe that what he did was supremely great". MARTIN JoHNSON

Probleme und Beispiele Biologischer Regelung Von Prof. R. Wagner. Pp. viii +219. (Stuttgart : Georg Thieme Verlag, 1954.) 29.40 D. marks.

T HIS book, the author of which is professor of physiology in Munich, is a discussion of biological processes from the point of view of servotheory. Being a biologist himself, Prof. R. Wagner is fully aware of the fact that a major theme of physiology from the times of Claude Bernard and Ludwig up to the present day has been to discover and study biological self-regulations. The results of this work are readily available for those who want to rewrite the classical findings in terms of servotheory.

Such pursuit in itself is an amusing intellectual exercise, and in this respect Wagner's book will not be found wanting. Criticism can only be levelled. against its treatment of reflex self-regulations of the muscle contraction, a field in which so much new material has come to light within the past years that Wagner's discussion is obsolete. The author does not recognize antidromic regulations as a likely possibility. Yet most nervous centres are provided with recurrent collaterals, and the antidromic feedback of the ventral horn cells is quite well understood. While in view of the general aims of the book this is not a serious criticism, it does, however, serve to emphasize the challenge of the experimenter, which is : What has servo-theory to offer as an aid to him in his work? Its mode of approach has now been presented many times to the biological world, propagandistically, but also unostentatiously, as in Wagner's book.

Would it be unfair to say that as a short-cut to experimental ingenuity servo-theory has not yet proved to be of much value compared with the resources of sound biological imagination? For the reply to this question the reader will have to turn to Wagner's work and judge for himself. Its author is a competent enough guide in both physiology and servo-theory.

British Pharmaceutical Codex, 1954

Pp. xxxii +1340 . (Published by direction of the Council of the Pharmaceutical Society of Great Britain.) (London: The Pharmaceutical Press, 1954.) $63 s$.

THE first edition of the "British Pharmaceutical Codex" was produced by the Pharmaceutical Society in 1907 ; the fifth revision has now appeared after an interval of only five years and is thinner than its predecessor. This book differs from the "Pharmacopœia" by being less exclusive, so that it gives information about a wider range of drugs the status of which is in doubt, and by the inclusion of information about the actions and uses of drugs.

The new edition contains two hundred pages fewer than its immediate predecessor, and this change has been achieved by deleting many of the less reputable drugs, some of which are still used. The "Codex" is becoming a guide to the drugs which ought to be used and is losing its value as a guide to all the drugs which actually are used. If it continues to develop in this direction, the time may come when it will be fused with the "Pharmacopoia", and a new book will be started to provide official information, of a less ambitious kind, about all the drugs which are actually in use. In the meantime, the "Extra Pharmacopœia" provides a useful summary of unofficial views about unofficial drugs.

The Revision Committee is to be congratulated on the way it has performed a prodigious task in a short time. The new book contains a great amount of reliable information about recent advances in therapeutics and will be invaluable to all concerned with the practical art of curing the sick.

\section{J. H. GADDUM}

\section{A Short History of Wool and its Manufacture (Mainly in England)}

By E. Lipson. Pp. vii +205 . (London: William Heinemann, Ltd., 1953.) 12s. 6d. net.

MOST of this book was published by the author V thirty-three years ago as "The History of the Woollen and Worsted Industries" (London, 1921). In writing the present volume, he might have advanced our knowledge of the subject in two ways : by adding a satisfactory account of the wool trade and industry's progress during and since the nineteenth century; and by revising and extending his account of earlier periods in the light of work pub. lished by other scholars since 1921. As it is, the chapter on the nineteenth and twentieth centuries is sketchy and slight: the usual account of basic technological developments to about 1850 ; their effects upon hand workers (but why illustrate the condition of hand-loom weavers by material relating 